\title{
ANALISIS DAYA DUKUNG TANAH PONDASI DALAM BERDASARKAN DATA LAPANGAN DI DESA BARINGIN KOTA PALANGKA RAYA
}

\section{ANALYSIS OF THE CARRYING CAPACITY OF DEEP FOUNDATION SOIL BASED ON FIELD RESULT IN BARINGIN VILLAGE, PALANGKA RAYA CITY}

\author{
Amanda Rachmad Pratama ${ }^{* 1}$, Rida Respati ${ }^{2}$, Norseta Ajie Saputra ${ }^{3}$ \\ ${ }^{1}$ Mahasiswa, Program Studi Teknik Sipil, Universitas Muhammadiyah Palangkaraya \\ ${ }^{2,3}$ Dosen, Program Studi Teknik Sipil, Universitas Muhammadiyah Palangkaraya \\ *Korespondensi: rachmad.pratama97@ gmail.com
}

\begin{abstract}
ABSTRAK
Daya dukung tanah adalah kemampuan tanah dalam mendukung beban pondasi yang bekerja di atasnya. Untuk menghasilkan daya dukung yang akurat, maka harus diketahui sifat dan karakteristik tanah. Untuk itu dilakukan perbandingan daya dukung tanah berdasarkan perhitungan CPT/ Sondir dan SPT untuk dapat merencanakan pondasi tiang yang aman dan ekonomis. Tujuan penelitian ini adalah untuk menentukan besarnya daya dukung tanah pada pondasi dalam di lingkungan sekitar Masjid Ataqwa Desa Baringin Kota Palangkaraya berdasarkan uji lapangan, dan berdasarkan uji laboratorium, serta untuk menentukan nilai hasil perbandingan Metode Mayerhof dan Metode Schmertmann-Nottingham. Berdasarkan data Sondir dilanjutkan perhitungan daya dukung tanah, kemudian hasil perhitungan dianalisis dan disimpulkan. Dari perhitungan Nilai Daya Dukung Pondasi tiang pelaksanaan titik 1 (satu) diperoleh nilai tertinggi pada tiang pancang diameter $400 \mathrm{~mm}$ pada metode mayerhoff sebesar $75.319 \mathrm{~kg}$ sedangkan nilai daya dukung terendah juga pada tiang pancang $400 \mathrm{~mm}$ sebesar $10.676 \mathrm{~kg}$. Untuk titik 2 (dua) diperoleh nilai tertinggi pada tiang pancang diameter $400 \mathrm{~mm}$ pada metode Shmertmann-Notingham sebesar $65.853 \mathrm{~kg}$ sedengkan nilai daya dukung terendah juga pada tiang pancang $400 \mathrm{~mm}$ sebesar $10.676 \mathrm{~kg}$.
\end{abstract}

Kata Kunci: Daya dukung tanah, pondasi, sondir

\section{ABSTRACT}

Soil bearing capacity is the ability of the soil to support the foundation load acting on it. To produce an accurate bearing capacity, it is necessary to know the properties and characteristics of the soil. For this reason, a comparison of the carrying capacity of the soil is carried out based on the calculation of CPT / Sondir and SPT to be able to plan a safe and economical pile foundation. The purpose of this study was to determine the amount of soil bearing capacity of the deep foundation in the environment around the Ataqwa Mosque, Baringin Village, Palangkaraya City based on field tests, and based on laboratory tests, and to determine the value of the comparison between the Mayerhof Method and the Schmertmann-Nottingham Method. Based on the Sondir value, it is continued with the calculation of the carrying capacity of the soil, then the calculation results are analyzed and concluded. From the calculation of the value of the carrying capacity of the foundation pile implementation of point 1 (one), the highest value of $400 \mathrm{~mm}$ diameter piles in the Meyerhoff method is 75,319 kg, while the lowest bearing capacity value is also at $400 \mathrm{~mm}$ piles of 10,676 $\mathrm{kg}$. For point 2 (two), the highest value is obtained at $400 \mathrm{~mm}$ diameter piles in the Shmertmann-Nottingham 
Analisis Daya Dukung .., Amanda Rachmad Pratama ${ }^{(1)}$, Rida Respati ${ }^{(2)}$, Norseta Ajie Saputra ${ }^{(3)}$

method of 65,853 kg, while the lowest bearing capacity value is also at $400 \mathrm{~mm}$ piles of 10,676 $\mathrm{kg}$.

Keywords: Cone penetration test, foundation, soil bearing capacity

\section{PENDAHULUAN}

Daya dukung tanah merupakan salah satu faktor penting dalam perencanaan pondasi beserta struktur diatasnya. Daya dukung tanah yang diharapkan untuk mendukung pondasi adalah daya dukung yang mampu memikul beban struktur, sehinga pondasi mengalami penurunan yang masih berada dalam batas toleransi. Pemilihan jenis dan desain bentuk fondasi tergantung pada jenis tanah lapisan tanah yang ada dibawahnya. Apabila lapisan tanah tersebut keras maka daya dukung tanah tersebut cukup kuat untuk menahan beban yang ada, sedangkan untuk tanah lunak diperlukan penanganan khusus agar mempunyai daya dukung yang baik.

Seperti tanah di Desa Baringin, Kota Palangka Raya secara umum memiliki daya dukung tanah yang cukup rendah termasuk jenis tanah lunak. Berdasarkan data laboratorium hasil penelitian diperoleh ukuran butir lolos saringan No.200 rata-rata $89,35 \%>50 \%$ hal tersebut menunjukkan tanah berbutir halus. Berat jenis (Gs) rata-rata 2,65. Batas berat jenis (Gs) 2,58 - 2,65 adalah jenis lempung organik (Muda, 2016).

Secara teoritis, beberapa ahli mekanika tanah menggembangkan metode-metode untuk menganalisis daya dukung tanah seperti ini pada umumnya menggunakan Minipile ataupun Boredpile. Metode-metode yang biasa digunakan untuk menghitung daya dukung tanah lunak antara lain, seperti metode Mayerhoff, dan Schmertmann-Notingham beberapa metode mempunyai keterbatasan dalam penggunaanya masingmasing. Metode tersebut memiliki pola keungulan yang berbeda.

Adapun tujuan dari penyelidikan tanah ini pada umumnya mencakup maksud sebagai berikut:

1. Untuk menentukan kondisi alamiah dan lapisan-lapisan tanah

2. Untuk mendapatkan sampel tanah asli (Undisturbed) dan tidak asli (disturbed) untuk mengidentifikasi tanah tersebut secara visual dan untuk keperluan pengujian laboratorium.

Penelitian ini akan dilakukan untuk mendapatkan daya dukung tana pondasi dalam berdasarkan data lapangan dengan beberapa metode yang berbeda diharapkan penelitian ini menghasilkan nilai daya dukung yang hampir sama atau sangat berbeda. Selain itu peneliti dapat memperoleh informasi tentang perbedaan dari beberapa metode tersebut.

\section{Rumusan Masalah}

Adapun rumusan masalah berdasarkan latar belakang yang telah diuraikan sebagai berikut:

1. Berapakah nilai daya dukung tanah pondasi dalam dengan menggunakan metode Mayerhof, dan Schmertmann-Notingham berdasarkan data lapangan.

2. Berapakah besarnya perbandingan daya dukung tanah pondasi dalam menggunakan kedua metode tersebut..

\section{Tujuan Penelitian}

Tujuan dari peneitian Analisis Daya Dukung Tanah Pondasi Dalam Bedasarkan Data Laboratorium adalah sebagai berikut:

1. Untuk menentukan nilai daya dukung tanah pondasi dalam dengan menggunakan metode Mayerhof dan Schmertmann-Notingham berdasarkan data lapangan.

2. Untuk menentukan besarnya perbandingan daya dukung tanah pondasi dalam menggunakan kedua metode tersebut.

\section{TINJAUAN PUSTAKA}

\section{Pondasi Tiang}

Pondasi tiang adalah suatu konstruksi pondasi yang mampu vertikal ke sumbu tiang dengan cara menyerap lenturan. Pondasi tiang dibuat menjadi satu kesatuan yang monolit dengan menyatukan pangkal tiang yang terdapat di bawah konstruksi dengan tumpuan pondasi.Pondasi tiang digunakan untuk suatu bangunan yang tanah dasar dibawah bangunan tersebut tidak mempunyai daya dukung (bearing capacity) yang cukup untuk memikul berat bangunan dan beban yang diterimanya atau apabila tanah pendukung yang mempunyai daya dukung yang cukup letaknya sangat dalam. 
Pondasi tiang ini berfungsi untuk menyalurkan beban-beban yang diterimanya dari konstruksi di atasnya kelapisan tanah yang lebih dalam. Teknik pemasangan pondasi tiang dapat dilakukan dengan pemancangan tiang-tiang baja/beton pracetak atau dengan membuat tiang-tiang beton bertulang yang langsung dicor di tempat (cast in place), yang sebelumnya telah dibuatkan lubang terlebih dahulu.

Pada perencanaan pondasi tiang pada umumnya diperkirakan pengaturan tiang-tiangnya terlebih dahulu seperti letak/susunan, diameter dan panjang tiang. Dalam pengaturan tiang-tiang tersebut perlu diperhatikan beberapa hal berikut:

1. Tiang yang berbeda kualitas bahannya atau tiang yang memiliki diameter berbeda tidak boleh dipakai untuk pondasi yang sama.

2. Tiang miring dipakai apabila besarnya gaya horizontal yang bekerja pada kelompok tiang terlalu besar untuk ditampung oleh tiang vertikal;

3. Jarak yang dianjurkan antara tiang dalam satu kelompok adalah antara 0,60 sampai 2,0 meter.

Pada umumnya gaya-gaya luar yang bekerja pada tiang yaitu pada kepala tiang yang meliputi berat sendiri bangunan di atasnya, beban hidup, tekanan tanah dan tekanan air. Sedangkan beban yang bekerja pada tubuh tiang yaitu meliputi berat sendiri tiang, gaya geser negatif pada selimut tiang dan gaya mendatar akibat getaran ketika tiang tersebut melentur.

\section{Sondir Test/Cone Penetration Test (CPT)}

Pengujian Cone Penetrometer Test atau sondir adalah pengujian dengan menggunakan alat sondir yang ujungnya berbentuk kerucut dengan sudut $60^{\circ}$ dan dengan luasan ujung $1,54 \mathrm{in}^{2}$ $\left(10 \mathrm{~cm}^{2}\right)$. Alat ini digunakan dengan cara ditekan ke dalam tanah terus menerus dengan kecepatan tetap $20 \mathrm{~mm} /$ detik, sementara itu besarnya perlawanan tanah terhadap kerucut penetrasi $\left(\mathrm{q}_{\mathrm{c}}\right)$ juga terus diukur.

Tujuan dari pengujian sondir ini adalah untuk mengetahui perlawanan penetrasi konus dan hambatan lekat tanah yang merupakan indikator dari kekuatan tanahnya dan juga dapat menentukan dalamnya berbagai lapisan tanah yang berbeda. Dari alat penetrometer yang lazim dipakai, sebagian besar mempunyai selubung geser (bikonus) yang dapat bergerak mengikuti kerucut penetrasi tersebut. Jadi pembacaan harga perlawanan ujung konus dan harga hambatan geser dari tanah dapat dibaca secara terpisah. Ada 2 tipe ujung konus pada sondir mekanis yaitu pada:

1. Konus biasa, yang diukur adalah perlawanan ujung konus dan biasanya digunakan pada tanah yang berbutir kasar, dimana besar perlawanan lekatnya kecil.

2. Bikonus, yang diukur adalah perlawanan ujung konus dan hambatan lekatnya dan biasanya digunakan pada tanah yang berbutir halus.

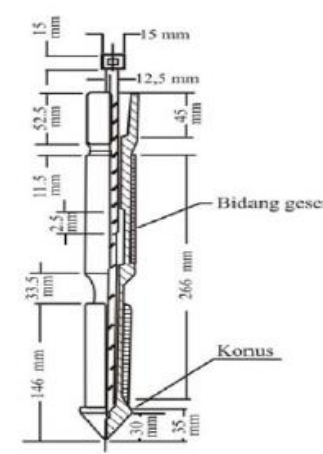

(a)

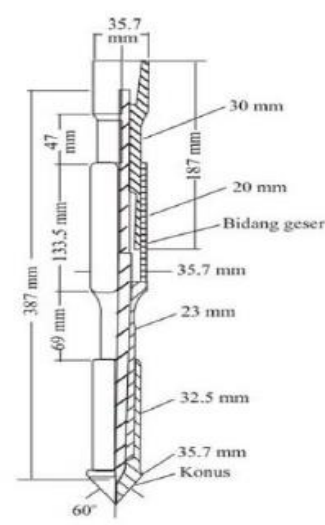

(b)
Gambar 1. Tipe Ujung Konus Sondir Mekanis

(a) Konus biasa

(b) Bikonus

Dari hasil sondir diperoleh nilai jumlah perlawanan (JP) dan nilai perlawanan konus (PK), sehingga hambatan lekat (HL) dapat dihitung sebagai berikut:

1. Hambatan Lekat (HL)

$\mathrm{HL}=(\mathrm{JP}-\mathrm{JK}) \times(\mathrm{A} / \mathrm{B})$

2. Jumlah Hambatan Lekat (JHL)

$\mathrm{JHL}=\Sigma \mathrm{HL}$

Dimana:

$\mathrm{JP}=$ Jumlah perlawanan, perlawanan ujung konus + selimut $(\mathrm{kg} / \mathrm{cm} 2)$

$\mathrm{PK}=$ Perlawanan penetrasi konus, $\mathrm{qc}(\mathrm{kg} / \mathrm{cm} 2)$

$\mathrm{A}=$ Interval pembacaan (setiap kedalaman 20 cm) )

$\mathrm{B}=$ Faktor alat luas konus/luas torak $=10 \mathrm{~cm}$

$\mathrm{i} \quad=$ Kedalaman lapisan tanah yang ditinjau (m)

\section{Kapasitas Daya Dukung Tiang - CPT}

Uji sondir atau Cone Penetration test (CPT) pada dasarnya adalah untuk memperoleh tahanan ujung qc dan tahanan selimut tiang c. Untuk tanah non - kohesif, Vesic (1967) menyarankan tahanan ujung tiang per satuan luas (fb) kurang lebih sama 
dengan tahanan konus (qc). Tahanan ujung ultimit tiang dinyatakan dengan persamaan:

$\mathrm{Qb}=\mathrm{Ab} \times \mathrm{qc}$

dimana:

$\mathrm{Qb}=$ Tahanan ujung ultimit tiang $(\mathrm{kg})$

$\mathrm{Ab}=$ Luas penampang ujung tiang $(\mathrm{cm} 2)$

$\mathrm{qc}=$ Tahanan konus pada ujung tiang $(\mathrm{kg} / \mathrm{cm} 2)$

Mayerhoff juga menyarankan penggunaan persamaan 3 tersebut, yaitu dengan qc rata-rata dihitung dari $8 \mathrm{~d}$ di atas dasar tiang sampai $4 \mathrm{~d}$ di bawah dasar tiang. Bila belum ada data hubungan antara tahanan konus dengan tahanan tanah yang meyakinkan, Tomlinson menyarankan penggunaan faktor $\omega$ untuk tahanan ujung sebesar 0,5 .

Metode yang paling sering digunakan dalam mengolah data CPT adalah metode langsung. Metode langsung dikemukakan oleh beberapa ahli diantaranya Meyerhoff dan Schmertmann-Nottingham. Pada metode ini, kapasitas daya dukung ultimit (Qult) yaitu beban maksimum yang dapat dipikul pondasi tanpa mengalami keruntuhan, dirumuskan sebagai berikut:

$\mathrm{Qult}_{\mathrm{u}}=\mathrm{qc} \times \mathrm{Ap}+\mathrm{JHL} \times \mathrm{K}$

Keterangan :

Qult= Kapasitas daya dukung maksimal/akhir $(\mathrm{kg})$

$\mathrm{qc}=$ Tahanan konus pada ujung tiang $(\mathrm{kg} / \mathrm{cm} 2)$

$\mathrm{Ap}=$ Luas penampang ujung tiang $(\mathrm{cm} 2)$

$\mathrm{JHL}=$ Tahanan geser total sepanjang tiang $(\mathrm{kg} / \mathrm{m})$

$\mathrm{K}=$ Keliling Tiang $(\mathrm{cm})$

$\mathrm{Q}_{\mathrm{iji}} \mathrm{n}$ yaitu beban maksimum yang dapat dibebankan terhadap pondasi sehingga persyaratan keamanan terhadap daya dukung dan penurunan dapat terpenuhi. Qijin dirumuskan sebagai berikut:

$\mathrm{Q}_{\mathrm{ijin}}=(\mathrm{Qc} \times \mathrm{Ap}) /(3)+(\mathrm{JHL} \times \mathrm{K}) / 5$

Keterangan:

$\mathrm{Q}_{\mathrm{ijin}}=$ Kapasitas daya dukung ijin tiang $(\mathrm{kg})$

$3=$ Faktor keamanan (diambil 3, 0)

$5=$ Faktor keamanan (diambil 5,0) Tarik:

Daya dukung kekuatan tanah untuk tiang

$\mathrm{T}_{\text {ult }}=\mathrm{JHL} \times \mathrm{K}$.
Daya dukung tiang tarik ijin :

$\mathrm{Q}_{\mathrm{ijin}}=\mathrm{T}_{\mathrm{ult}} / 3$.

\section{METODOLOGI PENELITIAN}

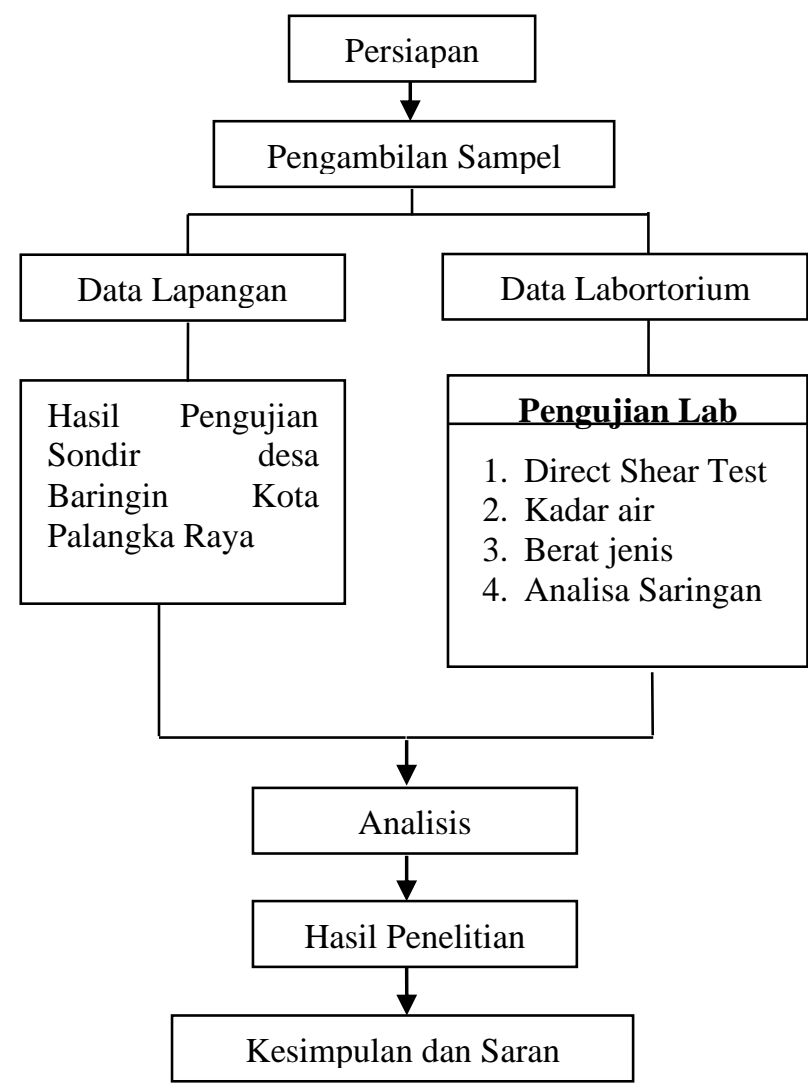

Gambar 2. Bagan Alur Penelitian

\section{Lokasi Pengambilan Sampel}

Lokasi pengambilan data lapangan ini di desa Baringin Kota Palangka Raya tepatnya pada kilometer 5,5 (Ruas Jalan Trans Palangka Raya-Buntok-Kuala Kurun).

\section{HASIL DAN PEMBAHASAN}

Pola penelitian yang dilakukan adalah menggunakan hasil pengujian sondir dan penyelidikan tanah undisturbed./tidak terganggu, penyelidikan tanah ini dilakukan di desa Baringin Bukit Rawi Kota Palangka Raya tepatnya di lahan komplek masjid At Taqwa Setelah dilakukan penelitian tanah asli desa Baringin Kota Palangka Raya di Laboraturium Fakultas Teknik Universitas Muhammadiyah Palangkaraya, diperoleh karakterisktik tanah melalui pengujian Analisa 
Saringan (sieve analysis), Berat Jenis (GS), Plastisitas Indeks (PI) seperti yang terlihat pada Tabel 1.

Tabel 1. Karakteristik tanah asli desa Beringin

\begin{tabular}{lcc}
\hline \multicolumn{1}{c}{ Jenis Pengujian } & Satuan & Hasil \\
\hline Lolos saringan no. 200 & $\%$ & 90,79 \\
Kadar air mula & $\%$ & 4,08 \\
Berat Jenis (GS) & - & 2,60 \\
Batas Cair (LL) & $\%$ & 51,90 \\
Batas Plastis (PL) & $\%$ & 27,59 \\
Plastisitas Indeks (PI) & $\%$ & 24,31 \\
Qc (Titik 1) & $\mathrm{Kg} / \mathrm{cm}^{2}$ & 150 \\
Fr (Titik 1) & $\%$ & 1,783 \\
Qc (Titik 2) & $\mathrm{Kg} / \mathrm{cm}^{2}$ & 125 \\
Fr (Titik 2) & $\%$ & 2,941 \\
Kohesi (titik 1) & $\mathrm{Kg} / \mathrm{cm}^{2}$ & 0,052 \\
Sudut Geser (titik 1) & $\mathrm{o}$ & 30,84 \\
Kohesi (titik 2) & $\mathrm{Kg} / \mathrm{cm}^{2}$ & 0,098 \\
Sudut Geser (titik 2) & $\mathrm{o}$ & 36,05
\end{tabular}

Sumber: Hasil Pengujian (2020)

Hasil pengujian analisa saringan diatas menunjukan bahwa dari sampel 500gr tanah yang diuji, persentase lolos saringan no.200 sebesar $92,16 \%$ atau 32,56gr dari 500gr sample tanah yg diuji lolos saringan no.200. Dimana, menurut AASHTO tanah yang lolos saringan no. 200 lebih dari $36 \%$ termasuk ke dalam klasifikasi jenis tanah lempung atau lanau dalam kelompok A-6, sedangkan menurut USCS jika sample tanah yang diuji dengan saringan no.200 lolosnya lebih dari $50 \%$ maka termasuk kedalam klasifikasi tanah berbutir halus.

\section{Hasil Pengujian Sondir/ CPT}

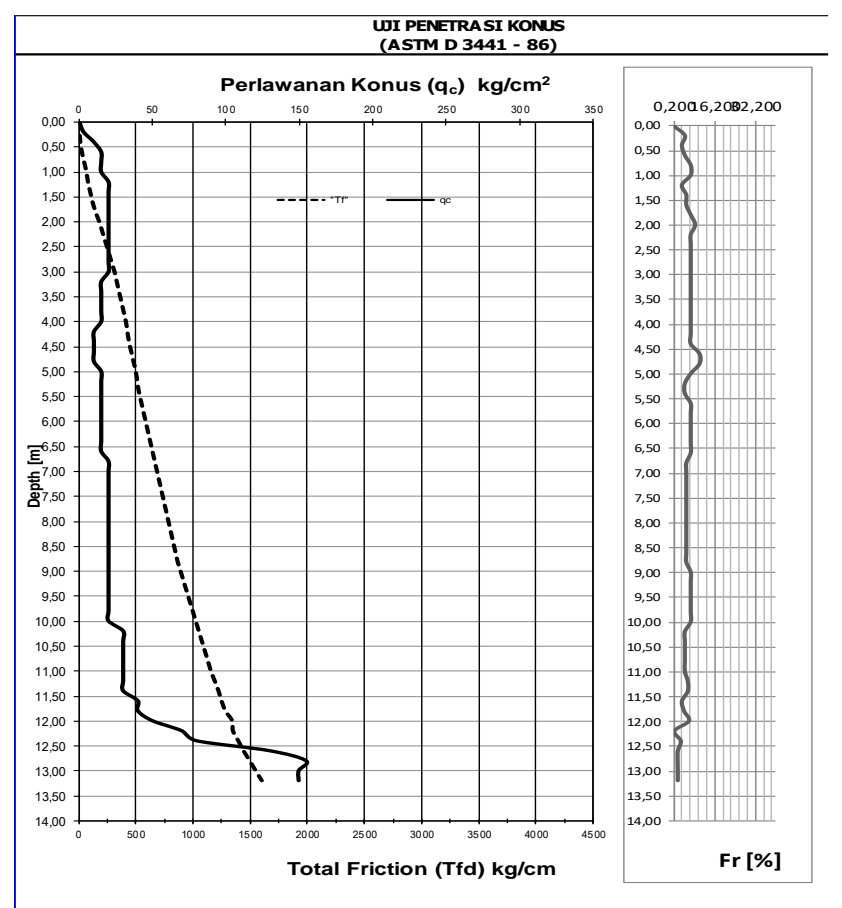

Gambar 3. Hasil Pengujian Titik 1 (satu)

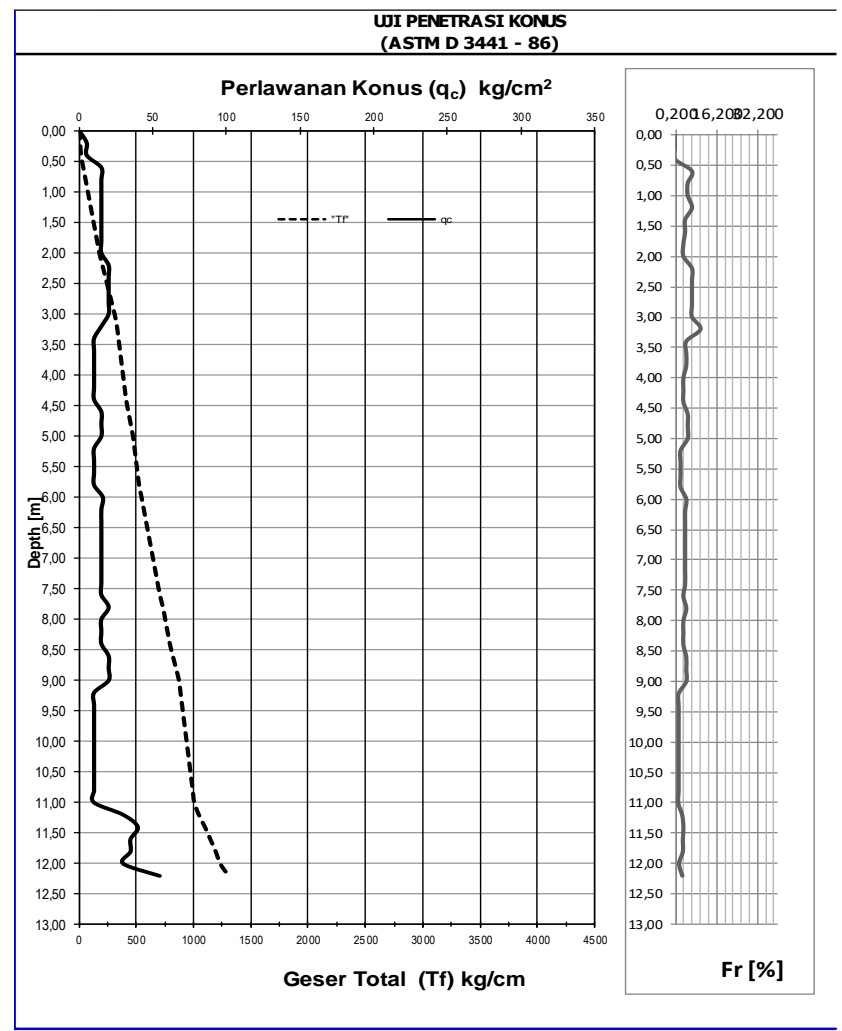

Gambar 4. Hasil Pengujian Titik 2 (dua)

\section{Hasil Pengujian Direct Shear Test (Dst)}

Pengujian kuat geser langsung ini dilakukan sebanyak tiga sampel pada tabung yang sama untuk mendapatkan nilai kohesi (c) dan sudut geser 
dalam $(\varphi)$. Hasil pengujian sebagaimana pada tabel berikut.

Tabel 2. Nilai Hasil Uji Direct Shear Test

\begin{tabular}{cccc}
\hline \multicolumn{4}{c}{ Titik 1 (satu) } \\
\hline \multirow{2}{*}{ Beban } & P1 & P2 & P3 \\
\cline { 2 - 4 } & 4,500 & 9,000 & 13,500 \\
\hline$\sigma\left(\mathrm{kg} / \mathrm{cm}^{2}\right)$ & 0,144 & 0,289 & 0,433 \\
$\tau$ maks $\left(\mathrm{kg} / \mathrm{cm}^{2}\right)$ & 0,208 & 0,280 & 0,401 \\
Kohesi $\left(\mathrm{kg} / \mathrm{cm}^{2}\right)$ & & 0,104 & \\
Sudut Geser $(\varnothing)$ & & $33,74^{\circ}$ \\
\hline \multicolumn{3}{c}{ Titik 2 (dua) } \\
\hline Beban & $\mathrm{P} 1$ & $\mathrm{P} 2$ & $\mathrm{P} 3$ \\
\cline { 2 - 4 } & 5,000 & 10,000 & 15,000 \\
\hline$\sigma\left(\mathrm{kg} / \mathrm{cm}^{2}\right)$ & 0,160 & 0,321 & 0,481 \\
$\tau$ maks $\left(\mathrm{kg} / \mathrm{cm}^{2}\right)$ & 0,218 & 0,318 & 0,422 \\
Kohesi $\left(\mathrm{kg} / \mathrm{cm}^{2}\right)$ & \multicolumn{3}{c}{0,115} \\
Sudut Geser $(\varnothing)$ & $32,50^{\circ}$ & \\
\hline Sum & \multicolumn{3}{c}{}
\end{tabular}

\section{Analisis Daya Dukung Ujung Tiang Pondasi Dalam}

Kapasitas/daya dukung tanah (bearing capacity) adalah kekuatan tanah untuk menahan suatu beban yang bekerja padanya yang biasanya disalurkan melalui pondasi. Adapun dalam melakukan analisa perhitungan daya dukung tanah berdasarkan data lapangan dilakukan dua cara atau metode rumus yang di pakai yaitu adalah metode Mayerhoff dan metode Schmertmann-Notingham. serta menentukan Safety Factor daya dukungnya pada hasil masing-masing metode yang dipakai Didalam penelitian tanah yang dilaksanakan ini digunakan pendekatan dengan 2 (dua) metode yang biasa digunakan yaitu metode Mayerhoff dan metode Schmertmann. Sebagai pembanding digunakan jenis tiang pancang yang sama untuk memperoleh nilai yang berbeda.

Sumber: Hasil Pengujian (2020)

Tabel 3 Hasil Nilai Daya Dukung Ujung Tiang

\begin{tabular}{ccccccc}
\hline & \multicolumn{3}{c}{ Metode Mayerhoff } & \multicolumn{3}{c}{ Metode Schmertmann - Notingham } \\
Diameter (mm) & $\mathbf{2 0 0}$ & $\mathbf{4 0 0}$ & $\mathbf{6 0 0}$ & $\mathbf{2 0 0}$ & $\mathbf{4 0 0}$ & $\mathbf{6 0 0}$ \\
\hline Titik 1 & $28.219 \mathrm{Kg}$ & $75.319 \mathrm{Kg}$ & $15.381 \mathrm{Kg}$ & $28.260 \mathrm{Kg}$ & $10.676 \mathrm{Kg}$ & $24.021 \mathrm{Kg}$ \\
Saampel I & & & & & & \\
Titik 2 & $25.602 \mathrm{Kg}$ & $65.853 \mathrm{Kg}$ & $13.026 \mathrm{Kg}$ & $32.185 \mathrm{Kg}$ & $10.676 \mathrm{Kg}$ & $24.021 \mathrm{Kg}$ \\
Sampel I & & & & &
\end{tabular}

Sumber: Hasil Perhitungan (2020)

Berdasarkan nilai yang diperoleh menunjukan bahwa dengan metode mayerhoff nilai daya dukung tiang bergerak meningkat dari penggunaan tiang pancang diameter 200 dengan nilai meningkat sampai dengan 400, sedangkan pada diameter 600 mengalami penurunan. Untuk metode Schmertmann-Notingham mengalami kondisi sebaliknya dimana nilai daya dukung tiang mengalami penurunan dari penggunaan tiang pancang diameter 400 kemudian mengalami peningkatan pada penggunaan tiang tiang pancang 600 namun tidak bisa melebihi nilai tiang pancang diameter 200.

Pada perhitungan daya dukung tiang pancang dengan metode Mayerhoff diperoleh nilai terendah dengan menggunakan diameter $600 \mathrm{~mm}$, nilai masing-masing $15.381 \mathrm{~kg}$ dan $13.026 \mathrm{~kg}$ (titik 1 dan titik 2) sedangkan nilai tertinggi pada penggunaan tiang pancang diameter $600 \mathrm{~mm}$ dengan nilai masing-masing $400 \mathrm{~mm}$. Untuk metode Schmertmann-Notingham hasi perhitungan nilai perhitungan daya dukung tiang pancang terendah pada penggunaan tiang pancang $400 \mathrm{~mm}$ denan nilai masing-masing $10.676 \mathrm{~kg}$ (titik 1 dan titik 2). Sedangkan nilai daya dukung tertinggi diperoleh pada penggunaan tiang pancang $200 \mathrm{~mm}$ dengan nilai masing-masing $28.260 \mathrm{~kg}$ dan 32.185 $\mathrm{kg}$.

Nilai daya dukung pondasi tiang penggunaan metode Mayerhoff dan Shmertmann-Notingham pada masing-masing titik pengambilan sampel dapat disampaikan dengan grafik dibawah ini.

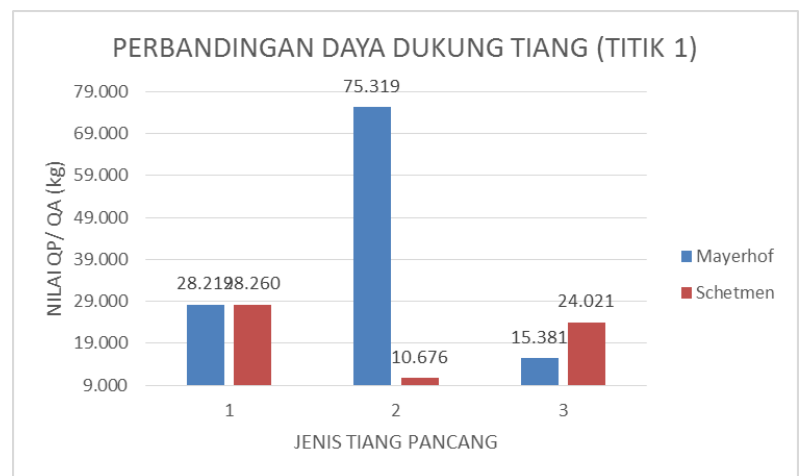

Gambar 4. Diagram Nilai Daya Dukung Tiang Pancang berdasarkan jenis Tiang (Titik 1) 
Pada Gambar 4 menunjukan hasil perhitungan daya dukung tiang pancang pada titik 1. Dari hasil perhitungan diketahui bahwa pada tiang pancang $200 \mathrm{~mm}$ penggunaan metode mayerhoff dan Schmertmann-Notingham memiliki nilai yang kurang lenih sama, untuk tiang pancang diameter $400 \mathrm{~mm}$ hasil perhitungan dengan metode mayerhof memperoleh nilai daya dukung yang lebih tinggi dari metode schmertmmen. Dan untuk penggunaan tiang pancang diamter $600 \mathrm{~mm}$ nilai daya dukung menggunakan metode Mayerhoff memperoleh nilai yang lebih rendah apabila dibandingkan dengan nilai hasil perhitungan metode Schmertmann-Notingham. Dari pelaksanaan titik 1 (satu) diperoleh nilai tertinggi pada tiang pancang diameter $400 \mathrm{~mm}$ pada metode mayerhoff sebesar $75.319 \mathrm{~kg}$ sedengkan nilai daya dukung terendah juga pada tiang pancang $400 \mathrm{~mm}$ sebesar $10.676 \mathrm{~kg}$.

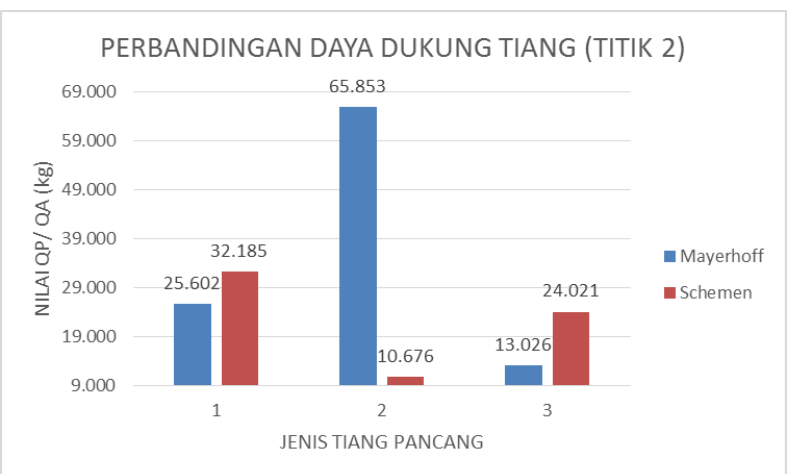

Gambar 5. Diagram Nilai Daya Dukung Tiang Pancang berdasarkan jenis Tiang (Titik 2)

Pada Gambar 5 menunjukan hasil perhitungan daya dukung tiang pancang pada titik 2. Dari hasil perhitungan diketahui bahwa pada tiang pancang $200 \mathrm{~mm}$ penggunaan metode Mayerhoff dan Schmertmann-Notingham memiliki niai yang berbeda dimana pada tiang pancang 200 mm penggunanan metode Schmertmann didapat nilai sebesar $32.185 \mathrm{~kg}$ sedangkan dengan menngunakan metode mayerhoff diperoleh nilai yaitu $25.602 \mathrm{~kg}$, hasil yang didapat lebih kecil. untuk tiang pancang diameter $400 \mathrm{~mm}$ hasil perhitungan dengan metode mayerhoff memperoleh nilai daya dukung yang lebih tinggi dari metode Schmertmann dimana nilai yang didapat untuk metode mayerhoff adalah $65.853 \mathrm{~kg}$ sedangkan untuk metode Schmertmann adalah $10.676 \mathrm{~kg}$.

Sedangkan untuk penggunaan tiang pancang diameter $600 \mathrm{~mm}$ nilai daya dukung menggunakan metode Mayerhof didapat hasil $13.026 \mathrm{~kg}$ memperoleh nilai yang lebih rendah bila dibandingkan dengan nilai hasil perhitungan metode Schmertmann-Notingham sebesar 24.021 kg. Dari pelaksanaan titik 2 (dua) diperoleh nilai tertinggi pada tiang pancang diameter $400 \mathrm{~mm}$ pada metode mayerhoff sebesar $65.853 \mathrm{~kg}$ sedengkan nilai daya dukung terendah juga pada tiang pancang $400 \mathrm{~mm}$ sebesar $10.676 \mathrm{~kg}$.

\section{PENUTUP}

\section{Kesimpulan}

1. Berdasarkan data lapangan maka diperoleh data kedalaman maksimum adalah 13,20 m dengan nilai qc $150 \mathrm{~kg} / \mathrm{cm} 2$ untuk titik pertama. Pada titik kedua diperoleh kedalaman maksimum $12,20 \mathrm{~m}$ dengan nilai qc $125 \mathrm{~kg} / \mathrm{cm} 2$

a. Nilai daya dukung tanah menggunakan metode Mayerhoff dengan jenis tiang yang berbeda pada sampel I titik I (satu) diperoleh hasil dengan diameter $200 \mathrm{~mm}$ pada kedalaman rencana $9 \mathrm{~m}$ diperoleh hasil sebesar $28.219 \mathrm{~kg}$, untuk tiang pada diameter $400 \mathrm{~m}$ didapatkan hasil sebesar $75.319 \mathrm{~kg}$, dan pada diameter $600 \mathrm{~mm}$ hasilnya $15.381 \mathrm{~kg}$. Sedangkan pada sampel I Titik II (dua) dengan kedalaman rencana $12,20 \mathrm{~m}$ nilai daya dukung dengan metode Mayerhoff diperoleh nilai pada tiang dengan diameter $200 \mathrm{~mm}$ sebesar $25.602 \mathrm{Kg}$, dan pada diameter $400 \mathrm{~mm}$ sebesar $65.853 \mathrm{Kg}$, sedangkan pada diameter $600 \mathrm{~mm}$ mengalami penurunan dengan hasil 13.026 $\mathrm{Kg}$.

b. Daya dukung tanah dengan menggunakan metode Schmertmann-Notingham pada sampel I titik I (satu) diperoleh nilai pada kedalaman $9 \mathrm{~m}$ dengan diameter $200 \mathrm{~mm}=$ 28.260 Kg, nilai kedalaman pada diameter $400 \mathrm{~mm}=10.676 \mathrm{Kg}$, nilai kedalaman pada diameter $600 \mathrm{~mm}=24.021 \mathrm{Kg}$. Sedangkan pada sampel I Titik II diperoleh nilai pada diameter $200 \mathrm{~mm}=32.185 \mathrm{Kg}$, nilai kedalaman pada diameter $400 \mathrm{~mm}=10.676$ $\mathrm{Kg}$, nilai kedalaman pada diameter $600 \mathrm{~mm}$ $=24.021 \mathrm{Kg}$.

2. Dari perhitungan Nilai Daya Dukung Pondasi tiang pelaksanaan titik 1 (satu) diperoleh nilai tertinggi pada tiang pancang diameter $400 \mathrm{~mm}$ pada metode mayerhoff sebesar $75.319 \mathrm{~kg}$ sedangkan nilai daya dukung terendah juga 
pada tiang pancang $400 \mathrm{~mm}$ sebesar $10.676 \mathrm{~kg}$. Untuk titik 2 (dua) diperoleh nilai tertinggi pada tiang pancang diameter $400 \mathrm{~mm}$ pada metode mayerhoff sebesar $65.853 \mathrm{~kg}$ sedangkan nilai daya dukung terendah juga pada tiang pancang $400 \mathrm{~mm}$ sebesar $10.676 \mathrm{~kg}$.

3. Pola yang terjadi berdasarkan nilai daya dukung pondasi tiang menunjukan bahwa dengan metode mayerhoff nilai daya dukung tiang bergerak meningkat dari penggunaan tiang pancang diameter $200 \mathrm{~mm}$ dengan nilai meningkat sampai dengan $400 \mathrm{~mm}$, sedangkan pada diameter $600 \mathrm{~mm}$ mengalami penurunan.

4. Sedangkan metode Schmertmann-Notingham mengalami kondisi sebaliknya dimana nilai daya dukung tiang mengalami penurunan dari penggunaan tiang pancang diameter $400 \mathrm{~mm}$ kemudian mengalami peningkatan pada penggunaan tiang tiang pancang $600 \mathrm{~mm}$ namun tidak bisa melebihi nilai tiang pancang diameter $200 \mathrm{~mm}$.

\section{Saran}

1. Perlu dilakukan perbandingan daya dukung tanah dengan menggunakan perhitungan manual dan perhitungan dengan Aplikasi Foundation Design atau aplikasi lainnya yang bersangkutan atau berhubungan dengan daya dukung tanah dan pondasi.

2. Dan untuk penelitian berikutnya agar lebih banyak menambahkan titik pengambilan data sondir dan sampel handboring dengan kedalaman yang bervariasi.

\section{DAFTAR PUSTAKA}

Bowles Joseph E. (1998) Analisis Dan Desain Pondasi, Edisi Keempat, Erlangga, Jakarta

Bowles, J.E. dan Hainim, J.K (1991). Sifat-sifat Fisis dan Geoteknik Tanah (Mekanika Tanah), Penerbit Erlangga, Jakarta.

Hardiyatmo, HC, 2010, Teknik Fondasi II, Penerbit Beta Offset, Yogyakarta

Martini, (2009) Pengaruh Tingkat Kepadatan Tanah Terhadap Daya Dukung Tanah. Universitas Tadulako, Palu.

Utami, (2013), Perbandingan Daya Dukung Tanah Berdasarkan Data Sondir dan SPT, Prosiding-Seminar Nasional, Teknologi Terapan (SN TEKPAN) 2013, Institut Teknologi Aditama Surabaya, Surabaya.
Putri A, AS, et all (2007), Penentuan Daya Dukung Tanah Berdasarkan Hasil Penentuan CPT dan Uji Laboratorium, Jurnal UNHAS, Universitas Hasanudin Makasar. 